aimed at with advanced students, not encyclopædic knowledge. Method was far more important than mere information. Advanced students should be left to work independently as much as possible. Research should be encouraged, but futile investigations were a mistake. Stress should be laid upon writing up the results of any piece of work in good literary form.

In the subsequent discussion, Prof. Miall said that in his elementary teaching at the Yorkshire College the laboratory work was the most important part of the work. Lectures were not given, but after a period in the laboratory a discussion on the facts observed took place in the lecture room, and the students were expected themselves to give an account of their work. They very soon learnt to express themselves clearly and easily, and had little difficulty in passing examinations. Prof. Marshall Ward agreed that observations formed a very important part of elementary botany, and children could be taught to reason from facts observed. With advanced students research was a powerful stimulus in developing interest in the subject. Prof. Withers believed that the study of science might well begin with natural history. Chemistry and physics should then be taken, and such a subject as botany might again be taken up in the higher forms. But as a training in scientific method he thought the value of botany was often extremely small.

Prof. Armstrong considered that more, attention might be given to systematic botany, and science altogether should be taken more seriously in schools, and at least half the school time should be given to practical work. Chemistry and physics, as well as botany, were required in order to give the student a good knowledge of scientific method. Dr. D. H. Scott said that there was often too much specialisation in the syllabuses drawn up for elementary classes. His experience as an examiner had shown him that the subject could be easily crammed without developing any real knowledge of the subject. Dr. Kimmins gave the opinion, as the result of his experience, that botany was often very badly taught in schools because of the want of properly trained teachers. He thought it was a pity that there was a tendency to replace it altogether by physics and chemistry.

Sir John Gorst said that it seemed to him that one of the best science subjects for purposes of general education was botany, especially for rural schools. The provision of laboratories and apparatus was a difficulty. Perhaps the County Councils might help with these. Properly trained teachers were required, and the subject should have attention in Training Colleges. Too many rural teachers at the present time were not properly qualified to give simple lessons in botany.

The chairman in closing the discussion said that it had been of great interest, and he felt that improvement would take place as soon as a good supply of properly trained teachers could be obtained.

\section{Organisation and Administration.}

The other subjects dealt with in the Section belong more to the organisation and administrative side of education than to the aims, scope and methods of science teaching, so a brief mention of them will be sufficient in these columns. Sir Henry Roscoe introduced the subject of the organisation of technical and secondary education, and in commenting upon it Sir Michael Foster said that whatever legislation was brought forward it was to be hoped that no distinction would be made between primary and secondary education. Sir Philip Magnus spoke in favour of the unification of educational effort by the creation of local authorities to be responsible for education in their areas. A paper by the Bishop of Hereford on the influence of the universities and examining bodies upon the work of schools contained a plea for the recognition of science and modern languages as substitutes for Greek in Responsions. It was pointed out that the existing requirement of Greek from every candidate desiring to enter the older universities, together with the accompanying exclusion of modern languages and science, practically dissociates the whole class of modern schools or modern departments in schools from direct university influence, and the effect is found to be specially unfortunate in the modern departments of the large secondary schools. The paper will be printed in full by the Association. Among other subjects discussed were commercial education, and the mechanism of education in Scotland. Dr. J. H. Gladstone also read his annual report on the teaching of science in elementary schools, hitherto presented to the chemistry section, but there were few other papers, the system adopted in the arrangement of the programme being to accept only one or two papers for each meeting, and these to be on definite topics requiring dis- cussion. By this means attention was concentrated upon particular aspects of educational work instead of being directed this way and that by a variety of papers. The system has worked so successfully that it will probably be followed at future meetings of the Section.

\section{FORTHCOMING BOOKS OF SCIENCE.}

Mr. Félix Alcan (Paris) gives notice of:- "Les maladies de l'orientation et de l'équilibre," by Prof. J. Grasset ; " Manuel d'Histologie pathologique," by Profs. V. Cornil and L. Ranvier, illustrated, tome second.

Among Mr. Edward Arnold's forthcoming books are :-_" The Balancing of Engines," by Prof. W. E Dalby, illustrated; "A Handbook on Fermentation and the Fermentation Industries," by Charles G. Matthews, illustrated; "Human Embryology and Morphology," by Dr. A. Keith, illustrated; "A Text-Book of Zoology," by G. P. Mudge, illustrated.

Messrs. George Bell and Sons give notice of :- " Elementary Science," by D. E. Jones and Dr. D. S. Macnair ; "Inorganic Chemistry," by Prof. James Walker, F.R.S. ; " $\Lambda$ n Introduction to the Comparative Anatomy of Animals," by Dr. G. C. Bourne, vol. ii. :-The Coelomata; "Elementary Differential Calculus," by Prof. A. Lodge, with an introduction by Prof. Oliver J. Lodge, F.R.S. ; "An Elementary Treatise on Cubic and Quartic Curves," by A. B. Basset, F.R.S.

Messrs. A. and C. Black promise :- "A Treatise on Elementary Statics" (for the use of schools and colleges), by W. J. Dobbs; "New Descriptive Geographies: Africa, Central and South America, North America," edited by Dr. A. J. Herbertson and F. D. Herbertson.

Messrs. Blackie and Son, Ltd., will issue :- " The World of Animal Life, an Introduction to the Wonders of the Animal World," illustrated.

In the list of the Cambridge University Press we notice:"Fables and Folk Tales from an Eastern Forest," collected and translated by Walter Skeat, illustrated; "Mathematical and Physical Papers," by Sir G, G. Stokes, F.R.S., vol. iii. "Scientific Papers," by Lord Rayleigh, F.R.S., vol. iii. It is expected that the work will be completed in four volumes. "The Electrical Properties of Gases," by Prof. J. J. Thomson, F.R.S.; "Electric Waves," being an Adams Prize Essay in the University of Cambridge, by H. M. Macdonald; "A Treatise on Determinants," by R. F. Scott. A new edition by (x. B. Mathews, F.R.S.; "The Algebra of Invariants," by J. H. Grace and A. Young; "A Primer of Botany," by F. F. Blackman; "Zoological Results based on material from New Britain, New Guinea, Loyalty Islands and elsewhere, collected during the years 1895, 1896 and 1897," by Dr. Arthur Willey. The entire work will be completed with the publication of part vi., which will be issued during 190I, and will contain Dr. Willey's monograph on Nautilus and other articles, including an account of the Ascidians by Prof. W. A. Herdman, F.R.S. "Reports of the Anthropological Expedition to Torres Straits by the Members of the Expedition," edited by Prof. A. C. Haddon, F.R.S., vol. ii. :-Physiology and Psychology. It is expected that the work will be completed in five volumes. "Biometrika. A Journal for the Statistical Study of Biological Problems," part i.; " The Fauna and Geography of the Maldive and Laccadive Archipelagoes," being the account of the work carried on and of the collections made by an expedition during the years 1899 and 1900 under the leadership of J. Stanley Gardiner, part i. of vol. i.; "Index Nominum Animalium," compiled by C. Davies Sherborn under the supervision of a committee appointed by the British Association and with the support of the British Association, the Royal Society and the Zoological Society, vol. i. .(1758-1800); "Fossil Plants," a manual for students of botany and geology, by A. C. Seward, F.R.S., vol. ii.; "Electricity and Magnetism," by Dr. R. T. Glazebrook, F.R.S., "Hegelian Cosmology," by J. McT. E. McTaggart ; "Essays on Educational Subjects," by Prof. S. S. Laurie.

Messrs. Cassell and Co., Ltd., will publish :- "The Earth's Beginning," by Sir R. S. Ball, F.R.S., illustrated ; and new editions of :- " Tumours, Innocent and Malignant, their Clinical Characters and Appropriate Treatment," by J. Bland Sutton, illustrated; "Surgical Applied Anatomy," by Sir Frederick Treves, K.C.V.O., assisted by Dr. Arthur Keith, illustrated. 
Messrs. W. and R. Chambers, Ltd., announce:-“The Nineteenth Century Series," in which we notice "Medicine, Surgery and Hygiene in the Century," by Dr. E. H. Stafford; "Discoveries and Explorations of the Century," by Prof. Charles G. D. Roberts; "Inventions of the Century," by William H. Doolittle ; "Progress of Education in the Century," by James Laughlin Hughes and Dr. Louis R. Klemm; "Progress of Science in the Century," by Prof. J. Arthur Thomson.

Among the forthcoming works of Messrs. Chapman and Hall, Ltd., we see :- "Steam Boiler Economy; a Treatise on the Theory and Practice of Fuel Economy in the Operation of Steam Boilers," by William Kent, illustrated ; "Elevation and Stadia Tables, for obtaining Differences of Altitude for all Angles and Distances, Horizontal Distances in Stadia Work, \&c., with all necessary Corrections, \&c.," by Arthur P. Davis; "Specifications for Steel Bridges," by J. A. L. Waddell ; "A Manual of Assaying ; the Fire Assay of Gold, Silver and Lead, including Amalgamation and Chlorination Tests," by Prof. Alfred Stanley Miller, illustrated; " High Temperature Measurements," by Prof. H. Le Chatelier and O. Boudouard, translated by George K. Burgess, illustrated; "Mechanical Drawing," by Lieut. Commander F. W. Bartlett, illustrated ; "Practical Workshop Mechanics," by Wallace Bently; "The Human Figure in Motion; an Electro-photographic Investigation of Consecutive Phases of Muscular Actions," by Eadward Muybridge, illustrated; "Intermediate Practical Physics; a Manual for the use of Intermediate and Preliminary Scientific Students," by John B. Wilkinson; and new editions of "Notes on Thermodynamics," by H. W. Spangler, part i. ; "A Textbook of Mechanical Engineering," by Wilfrid J. Lineham, illustrated.

Messrs. J. and A. Churchill's list contains :-_"A Manual on Anatomy," by the late Prof. Alfred W. Hughes, edited by Prof. Arthur Keith; "Clinical Essays and Lectures" by Howard Marsh ; "Gynæecological Pathology," by Dr. Charles Hubert Roberts, illustrated " "The Bacteriological Examination of Water," by Major Horrocks; "Serum-Therapy," by Prof. R. T. Hewlett ; "A Text-Book of Clinical Medicine," by Dr. T. D. Savill; "A Hand-Book of Nursing, Medical and Surgical," by Dr. Hadley ; "Elementary Ophthalmic Optics, including Ophthal moscopy and Retinoscopy," by J. Herbert Parsons ; vol. 4 of Groves' and Thorpe's "Chemical Technology"; "Electric Lighting and Photometry," by W. T. Dibdin and G. E. Cooke and new editions of :- "A Manual of the Practice of Medicine," by Dr. Frederick Taylor; "A Text-Book of Medicine," edited by Dr. Pye-Smith, vol. i. ; "Chemistry, Inorganic and Organic," by Prof. John Millar Thomson and Arthur G. Bloxam; "A Short Manual for Monthly Nurses," by Dr. Cullingworth; "A Simple Method of Water Analysis," by Dr. John C. Thresh; "The Pharmacopoia of the Throat Hospital" ; "Dissection Outlines for use with Morris's Treatise on Anatomy."

The Clarendon Press announces:- "Micro-Anatomy," by Gustav Mann.

Messrs. J. M. Dent and Co. announce :-"A Primer of Physiology," by Dr. Alex. Hill ; "Northern Mythology," by Prof. Kaufmann; "Beautiful Birds," by Edmund Selous.

Messrs. Duckworth and Co. will publish :-A new edition in one volume of "The Country Month by Month," by J. A. Owen ("A Son of the Marshes") and Prof. G. S. Boulger, with Notes by the late Lord Lilford.

Mr. Gustav Fischer (Jena) announces :- "Abhandlungen, Geologische und Palrontologische," edited by E. Koken, band v. heft I ; "Geologie der Radstädter Tauern," by Prof. F. Frech, illustrated; "Zur Lehre von der Blutzirkulation in der Schädelhöhle des Menschen, namentlich unter dem Einfluss von Medikamenten," by Dr. Hans Berger ; "Fauna Arctica," edited by Dr. Fritz Römer and Dr. Fritz Schaudinn, zweiter band, erste lieferung; "Die Dipsomanie," by Dr. Robert Gaupp; "Die Malaria," by Battista Grassi, zweite vermehrte aufiage; "Handbuch der Geschichte der Medizin," edited by Prof. Max Neuburger and Julius Pagel, erste lieferung; "Das Agglutinationsphänomen," by Dr. Fritz Köhler; "Topographischer Atlas der medizinischen Diagnostik," by Prof. Ponfick, zweite lieferung; "Handbuch der Hygiene," edited by Dr. Th. Weyl, erster supplementband, erstes heft ; "Bedeutung eines systematischen Studiums des Skleroms," by Dr. von Schrötter; "Lehrbuch der vergleichenden Entwickelungsgeschichte der wirbellosen Thiere," by Profs. E. Korschelt and
K. Heider, ' allgemeiner teil ; "Technische Mykologie," by Prof. F. Lafar, zweiter band, erste lieferung ; "Normentafeln zur Entwickelungsgeschichte der Wirbeltiere," edited by Prof. Dr. F. Keibel, drittes heft, illustrated ; "Tropenhygiene mit spezieller Berïcksichtigung der Deutschen Kolonien," by Prof. F. Plehn; "Die Bakterien," by Drs. J. Schmidt and Weis, illustrated.

The announcements of Messrs. Charles Griffin and Co., Ltd., include :- " Trades' Waste, its Treatment and Utilisation, with Special Reference to the Prevention of Rivers' Pollution," by W. Naylor; "The Metallurgy of Steel," by F. W. Harbord, illustrated ; "Elementary Coal-Mining, for the Use of Students, Miners, and others preparing for Examinations," by George L. Kerr, illustrated ; "A Dictionary of Textile Fibres," by William I. Hannan, illustrated; "Sanitary Engineering, a Practical Manual of Town Drainage and Sewage and Refuse Disposal," by Francis Wood, illustrated ; "Ferments and their Action, a Text-book on the Chemistry and Physics of Fermentative Changes," by Dr. Carl Oppenheimer, translated by C. Ainsworth Mitchell ; "Tables and Data for the Use of Analysts, Chemical Manufacturers, and Scientific Chemists," by Prof. J. Castell-Evans, in 2 vols. ; "A Text-Book of Physics," by Prof. J. IH. Poynting, F.R.S., and J. J. Thomson, F.R.S., illustrated, introductory volume on Properties of Matter; "Diseases of the Organs of Respiration, an Epitome of the Etiology, Pathology, Diagnosis and Treatment of Diseases of the Lungs and Air Passages," by Dr. Samuel West, illustrated "Official Year-Book of Scientific and Learned Societies of Great Britain and Ireland," eighteenth annual issue.

Mr. W. Heinemann's list includes :- "The Play of Man," by Prof. Karl Groos, translated with the author's cooperation by Elizabeth L. Baldwin; "The Regions of the World," a series of twelve volumes descriptive of the physical environment of the nations, edited by H. J. Mackinder :"Britain and the British Seas," by the Editor; "The Near East," by D. G. Hogarth ; "Western Europe and the Mediterranean," by Elisée Reclus ; "Central Europe," by Dr. Joseph Bastoch ; "Scandinavia and the Arctic Ocean," by Sir Clements R. Markham, F.R.S.; " "The Russian Empire," by Prince Kropotkin ; "Africa," by Dr. J. Scott Keltie; "India," by Colonel Sir Thomas Holdich; "The Far East," by Archibald Little; "North America," by Dr. Israel C. Russell ; "South America," by Dr. John C. Branner; "Australasia and Antarctica," by Dr. H. O. Forbes.

Mr. H. K. Lewis's list is as follows :- "A Handbook of Bacteriological Diagnosis for Practitioners, including Instructions for the Clinical Examination of the Blood," by Prof. W. d'Este Emery, illustrated ; "Transactions of the Dermatological Society of Great Britain and Ireland," vol. vii.; and new editions of :- "Elements of Practical Medicine," by Prof. A. H. Carter; "The Sanitary Inspector's Handbook," by Albert Taylor, illustrated; "Rough Notes on Remedies," by Dr. William Murray.

Messrs. Crosby Lockwood and Son announce :-" Prospecting for Gold," by D. J. Rankin, illustrated ; "Mining Calculations, comprising Arithmetic, Algebra and Mensuration," by T. A. O'Donahue, illustrated; "The Pocket-book of Refrigeration and Ice-Making for I902, with Diary," edited by A. J. WallisTayler; "The Bacterial Purification of Sewage," by Dr. Sidney Barwise, illustrated ; and new editions of "Water and its Purification, a Handbook for the Use of Local Authorities, Sanitary Officers, and others interested in Water Supply," by Dr. S. Rideal, illustrated ; " Lockwood's Dictionary of Terms used in the Practice of Mechanical Engineering," edited by Joseph G. Horner; "The Health Officer's Pocket-book, a Guide to Sanitary Practice and Law," by Dr. Edward F. Willoughby, illustrated.

Messrs. Longmans and Co.'s list contains :- "The Great Deserts and Forests of North America," by Paul Fountain; "Human Personality and its Survival of Bodily Death," by Frederic W. H. Myers, 2 vols. ; "Dreams and their Meanings," by Horace G. Hutchinson ; "Intuitive Suggestion," by J. W. Thomas ; "Higher Mathematics for Students of Chemistry and Physics, with Special Reference to Practical Work," by I. W. Mellor ; "A Practical Guide to the Administration of Anæsthetics," by Dr. R. J. Probyn-Williams ; "A Practical Treatise on Mine Surveying," by Arnold Lupton, illustrated "Bricklaying and Brick-cutting," by H. W. Richards, illustrated; "The Mind of a Child," by Ennis Richmond.

Messrs. Sampson Low and Co., Ltd., promise :-"The

No. [667, VOL. 64] 
Nordrach Treatment for Consumptives in this Country," by Tames Arthur Gibson; and a new edition of "The Student's Chemistry," by R. L.·Taylor.

Among the announcements of Messrs. Macmillan and Co., Ltd., we notice :- "The Sherbro and its Hinterland," by T. J. Alldridge, illustrated; "The Scientific Memoirs of Thomas Henry Huxley," edited by Sir M. Foster, K.C.B., F.R.S., and Prof. E. Ray Lankester, F.R.S., in 4 vols., vol. iv. ; "Atlas of Practical Elementary Zootomy," being a revised edition of the zoological portion of the "Atlas of Practical Elementary Biology," by Prof. G. B. Howes, F.R.S., with a preface to the first edition by the late Prof. T. H. Huxley, P.C., F.R.S. ; "The Scenery of England and the Causes to which it is due," by the Right Hon. Lord Avebury, F.R.S., illustrated ; Macmillan's Manuals of Medicine and Surgery: "A Manual of Medicine," edited by Dr. W. H. Allchin, vol. iv. Diseases of the Respiratory System and of the Circulatory System, vol. v. Diseases of the Digestive System and of the Kidneys; "Assimilation and Digestion," by Sir T. Lauder Brunton, M.D., F.R.S. ; "The Climates and Baths of Great Britain" being the Report of a Committee of the Royal Medical and Chirurgical Society of London, vol. ii. The Midland Counties and Ireland; "Outlines of Inorganic Chemistry," by Prof. W. Ostwald, translated by Dr. Alex. Findlay; "An Experimental Study of Gases," by Morris W. Travers, with a preface by Prof. William Ramsay, F.R.S. ; "Lectures and Essays by the late William Kingdon Clifford, F.R.S.," edited by Leslie Stephen and Frederick Pollock, with an introduction by F. Pollock, third edition, in 2 vols. ; "Philosophy, Its Scope and Method," a course of introductory lectures by the late Prof. Henry Sidgwick; "The Growth of Hegel's Logic," by J. B. Baillie ; "Mind in Evolution," by L. T. Hobhouse ; "Texts for a Course of Elementary Lectures on the History of Greek Philosophy," edited by Dr. Henry Jackson ; "Mammals," by F. E. Beddard, F.R.S. (being vol. x. of the Cambridge Natural History); "Insect Life, Souvenirs of a Naturalist," by M. J. H. Fabre, translated from the French by the Author of "Mademoi. selle Mori," with a preface by Dr. David Sharp, F.R.S., illustrated;" The Mystic Rose, a Study of Primitive Marriage," by A. E. Crawley; "An Elementary Treatise on the Calculus," by Prof. George A. Gibson; a new edition of "The History of Human Marriage," by Dr. Edward Westermarck, with preface by Dr. A. R. Wallace, F.R.S.; "Upland Game Birds," by Emerson Hough, illustrated; "Salmon, Trout," by Dean Sage and A. Nelson Cheney, illustrated; "The Deer Family," by the Hon. Theodore Roosevelt, T. S. Van Dyke, and H. G. Stone, illustrated; "Municipal Engineering and Sanitation," by M. N. Baker; "An Introduction to Celestial Mechanics," by Dr. Forest Ray Moulton; "Elementary Electricity and Magnetism," by Profs. D. C. Jackson and J. P. Jackson, illustrated; "A Primer of Calculus," by Arthur S. Hathaway, illustrated; "The Practical Methods of Organic Chemistry," by Prof. Ludwig Gattermann, a new edition of the authorised translation by Dr. William B. Shober, illustrated; "The Applications of the Kinetic Theory to Gases, Vapours, Pure Liquids, and Solutions," by Dr. William Pingry Boynton, illustrated ; "The Protozoa," by Dr. Gary N. Calkins, illustrated ; "The Röntgen Rays in Medicine and Surgery, as an Aid in Diagnosis and as a Therapeutic Agent," by Dr. Francis H. Williams, illustrated ; " Cyclopædia of American Horticulture," edited by Prof. L. H. Bailey, illustrated, vol. iv., completing the set; "First Lessons in Agriculture," by Prof. L. H. Bailey ; "University Text-book of Botany," by Prof. Douglas Houghton Campbell, illustrated; "The Principles of Stock Breeding, the Application of Biological Laws to the Breeding of Domestic Animals (including Poultry), whether for Fancy or Profit," by Prof. W. H. Brewer ; "Dictionary of Philosophy and Psychology," edited by Prof. James Mark Baldwin, with an international body of collaborators, in 3 vols. ; "A Student's History of Philosophy," by Prof. Arthur Kenyon Rogers : "An Introduction to Psychology," by Prof. Mary Whiton Calkins ; "Mental Growth and Control," by Dr. Nathan Oppenheim; "The College Student and his Problems," by Dr. James H. Canfield; "The Child's First Book in Science," by Dr. Edward S. Holden, illustrated.

Messrs. Methuen and Co. will publish :- "Head-Hunters, Black, White and Brown," by Prof. A. C. Haddon, F.R.S., illustrated.

Mr. Murray's list includes :- "National Education, a SymNO. I667, vOL. 64] posium," edited by Laurie Magnus; "Tubulous Boilers, based on a Short Course of Lectures delivered at University College, London," by Leslie S. Robertson, illustrated; "The Fixed Stars, an Exposition of that Branch of Astronomy which relates to them," by Prof. Newcomb; "Heredity," by Prof. J. Arthur Thomson, illustrated (Progressive Science Series); "The Dawn of Modern Geography, a History of Exploration and Geographical Science from the opening of the Tenth to the middle of the Thirteenth Century (A.D. 900-1250)," by C. Raymond Beazley, illustrated; "Dangerous Trades, the Historical, Social and Legal Aspects of Industrial Occupations as affecting Public Health," by a number of experts, edited by Dr. T. Oliver, illustrated ; "The Natural History of Religion, based on the Gifford Lectures delivered in Aberdeen in I889-90 and 1890-91," by Prof. Edward Burnett Tylor, F.R.S., illustrated ; "The Soil," by A. D. Hall; "The Book of Ser Marco Polo, the Venetian, concerning the Kingdoms and Marvels of the East," translated and edited by the late Colonel Sir Henry Yule, revised throughout in the light of modern discoveries, with a memoir of Colonel Yule (compiled with the assistance of Miss Yule), by Prof. Henri Cordier, 2 vols., illustrated.

Messrs. George Newnes, Ltd., will publish in the Library of Useful Stories Series :- "The Story of Animal Life," by B. Lindsay, illustrated; "The Story of Euclid," by W. B, Frankland.

In the list of Messrs. Kegan Yaul, Trench, Truibner and Co. Ltd., we observe:-“"Assyrian Language, Easy Lessons in Cuneiform Inscriptions," by L. W. King; "The Book of the Dead, an English translation of the Theban Recension," with supplementary chapters, hymns, \&c., and nearly 400 vignettes which do not appear in the larger edition published in 1897 , by Dr. E. A. Wallis Budge ; and a new edition of "Text-Book of Physiological and Pathological Chemistry," by G. Bunge, translated from the German edition by Florence Starling.

Messrs. G. P. Putnam's list includes :-_"Zuni Folk-Tales," by F. H. Cushing, illustrated; "The Home Life of the Wild Birds," by F. H. Herrick, illustrated ; and a new edition of “Thinking, Feeling, Doing," by E. W. Scripture, illustrated.

Mr. Grant Richards announces new editions of "Colin Clout's Calendar," by Grant Allen; and "Logic, Deductive and Inductive," by Carveth Read.

Messrs. Rivingtons announce :- "Chinese Turkestan, with Caravan and Rifle," by Percy W. Church ; "Rivingtons" Junior Mathematics," by H. G. Willis, comprising Arithmetic, two parts ; Algebra, two parts.

Messrs. F. E. Robinson and Co. will issue :-"Wild Sport in the Outer Hebrides," by C. V. A. Peel.

Mr. Walter Scott announces:- " History of Geology and Palæontology to the End of the Nineteenth Century," by Prof. Karl von Zittel, translated by Dr. M. M. Ogilvie-Gordon, illustrated; "The Study of Religion," by Prof. Morris Jastrow, jun.

Messrs. Seeley and Co., Ltd., promise :-A new and enlarged edition of "The Chemistry of Paints and Painting," by Prof. A. H. Church, F.R.S.

Messrs. Smith, Elder and Co. call attention to:- "Lectures on Chemical Pathology in its Relation to Practical Medicine, delivered at the University and Bellevue Medical School, New York City," by Prof. C. A. Herter.

Messrs. Sonnenschein and Co., Ltd., have in hand:"Harlyn Bay and the Discovery of its Prehistoric Remains," by the Rev. R. A. Bullen ; Heinze's " History of Contemporary Philosophy," translated by Prof. W. Hammond; Wundt's "Physiological Psychology," translated by Prof. E. B. Titchener ; "The Student's Text-book of Zoology," by A. Sedgwick, F.R.S., vol. ii. ; "Psychology, Normal and Morbid," by Dr. C. A. Mercier ; and new editions of Hertwig's "Elements of Embryology," and Walters' "Sanatoria for Consumptives."

Mr. Fisher Unwin will issue :- "Alcoholism-a Study in Heredity," by Dr. G. Archdall Reid.

\section{UNIVERSITY AND EDUCATIONAL} INTELLIGENCE.

CAMBridge. - A research studentship of $120 l$, tenable for one year, has been awarded at Emmanuel College to Mr. G. L. Tuck.

THE new pathological laboratory at Oxford is to be opened by Sir William Church on Saturday next. 